\title{
Kekuatan Terapi Syukur dalam Membentuk Pribadi yang Altruis: Perspektif Psikologi Qur'ani dan Psikologi Positif
}

\author{
Mohammad Takdir ${ }^{1}$ \\ Institut Ilmu Keislaman Annuqayah (INSTIKA), Madura
}

\begin{abstract}
This paper aims to elaborate the therapy power of gratitude in the shaping of the altruistic personality. This research used a comparative study of quranic psychology and positive psychology as a reference to explain about therapy power of gratitude. This research used a psychological approach to reveal the influence of the grateful on the meaningfulness of life.The results showed grateful in quranic psychology is a form of recognition of the favors bestowed by God with the submission and obedience according to what has been commanded. Gratitude in quranic psychology can be practiced in the three ways, namely orally grateful, heart, and deed. Gratitude in positive psychology is an emotional positive reaction in response to the receipt of a gift and benefit from someone. Gratitude in this perspective can be practiced personally (be thankful to the people who has given a gift) and transpersonal (expression of gratitude to God who has given many gifts in this world). In quranic psychology, be grateful can be Sufi healing or therapy to cure individualistic attitude into the life of the society. In positive psychology perspective, becoming a thankful person tend to be more generous and humble, if compared with those who never grateful.
\end{abstract}

Kata Kunci: Terapi; Syukur; Altruis; Psikologi Qur'ani; Psikologi Positif.

\section{Pendahuluan}

Gerakan untuk membiasakan rasa syukur atas nikmat Tuhan seharusnya menjadi gerakan bersama dalam rangka mencapai potensi kebahagiaan dan ketenangan hidup yang lebih ideal. Tulisan ini memberikan gambaran secara detail mengenai pemanfaatan terapi syukur dalam setiap aspek kehidupan yang selalu diwarnai oleh ketidakpuasan dalam menerima limpahan rahmat dari Tuhan. Pola keterampilan rohani ini bisa memberikan tuntunan bagi setiap orang dalam melejitkan kecerdasan dan emosionalnya menjadi insan kamil yang menghargai pengabdian secara total kepada Allah. Terapi syukur memang lebih mencerminkan dimensi psikologis sebagai jawaban atas krisis makna hidup yang menimpa manusia modern. Dengan membiasakan hidup sederhana dan qanaah, minimal manusia

\footnotetext{
${ }^{1}$ Korespondensi untuk tulisan ini ditujukan kepada email mohammad.takdir@yahoo.com
} 
telah menjadikan perilaku syukur sebagai spirit untuk mengubah gaya hidup yang hedonistik menjadi pribadi yang altruis.

Terapi syukur merupakan pengembangan potensi fitrah yang menekankan pada kecerdasan manusia dalam mendayagunakan segenap rezeki Tuhan dengan tetap berprasangka baik kepada sang pencipta. Meskipun Allah memberikan rezeki yang sedikit, namun bila manusia cerdas dalam memanfaatkan potensi rezeki itu, maka Allah akan memberikan kecukupan dari aspek kepuasaan batin yang tercermin dari pengabdian dalam menjalankan perintah Allah. Perilaku syukur yang tercermin dalam tulisan ini diharapkan menjadi terapi mujarab bagi setiap manusia untuk menjadi pribadi yang altruis, sebuah sikap atau perilaku yang mengutamakan orang lain dan senang berbagi kebaikan kepada sesama tanpa membedakan latar belakang kehidupan.

Terapi syukur ini dapat dimaknai sebagai sebuah latihan mental untuk membiasakan perilaku positif dalam rangka memanfaatkan pemberian Allah dengan penuh totalitas. Pemanfaatan rezeki yang diberikan Allah kepada setiap manusia merupakan bentuk ketaatan seorang hamba dalam menerima apa saja tanpa ada perasaan mengeluh atau berkeluh kesah, apalagi berprasangka negatif dengan ketentuan Allah. Bila dilacak makna "kuantum" yang terdapat dalam zona syukur, maka akan menemukan hikmah yang luar biasa dari potensi kedahsyatan perilaku bersyukur dalam berbagai aspek kehidupan, terutama berpengaruh pada sikap empatik terhadap orang lain yang membutuhkan uluran tangan.

Sebagai perilaku atau sikap yang berdimensi teologis dan psikologis, tulisan ini diharapkan memberikan energi positif bagi semua orang untuk memanfaatkan potensi kefitrahannya yang sejak lahir sudah tertanam nilai-nilai kebersyukuran. Intinya, akses untuk merengkuh kesuksesan dan kebermaknaan hidup hanya bisa dicapai apabila setiap orang mampu menerapkan latihan syukur dengan berbagi nikmat dengan orang lain. Jika manusia bisa mengoptimalkan potensi fitrah ini dalam menjalani kompleksitas kehidupan, maka akan memperoleh limpahan rahmat yang tidak terduga dari berbagai penjuru dunia ini.

Perilaku syukur merupakan salah satu bentuk kecerdasan spiritual (spiritual quotient) yang bisa memberikan energi dahsyat bagi manusia dalam memperoleh ketenangan dan kedamaian. Energi yang terdapat dalam zona syukur bisa membuat manusia tegar dalam 
menghadapi semua ketentuan Tuhan. Seseorang yang menyadari dan memanfaatkan pola kecerdasan ini, akan mampu menjadikan kegagalan sebagai modal meraih kesuksesan, musibah sebagai ujian, jubah kepangkatan menjadi kain kafan, kecemasan menjadi ketenangan, marah menjadi senyuman, dan kekayaan menjadi ladang memperbanyak amal. ${ }^{2}$ Tidak heran bila pola keterampilan yang berdimensi psikologis ini dapat disebut sebagai sebuah miracle atau keajaiban yang dikaruniakan Allah kepada hamba-Nya yang benar-benar bertaqwa dan beriman dengan penuh keikhlasan.

Dari sini, energi yang terdapat dalam terapi syukur bisa menjadi gerakan bersama untuk mengendalikan nafsu keserakan dan ketamakan dalam diri yang selalu mendorong seseorang mengejar ambisi dan hasrat yang tidak terkendali. Terapi syukur bisa menjadi instrumen konseling dalam mengubah perilaku hidup manusia yang seringkali mengabaikan hak-hak orang lain. Sebagai bagian dari maqam sufi, perilaku syukur bisa menjadi terapi untuk mengendalikan hasrat dan keinginan manusia yang sering terjebak dengan kemewahan sesaat. Jika terapi syukur bisa diimplementasikan dalam kehidupan sehari-hari, baik dalam ruang lingkup keluarga, masyarakat, dan kehidupan bernegara, maka pada gilirannya akan membentuk generasi yang altruis dan shaleh secara sosial.

\section{Pribadi Altruis}

Menjadi pribadi altruis dalam dimensi sosial memang tidak mudah sebagaimana yang dibayangkan. Ini karena, karakter altruistik hanya melekat pada pribadi-pribadi yang sudah ditempa dengan berbagai macam cobaan dalam menghadapi kehidupan yang penuh dengan tantangan ini. Orang yang memiliki karakter altruistik adalah orang yang mampu menghilangkan egoisme dalam dirinya dan selalu bersikap sosial terhadap orang lain tanpa memandang latar belakang kehidupan, baik perbedaan suku, adat istiadat, budaya, bahasa, maupun agama.

Altruisme dipahami sebagai sebuah faham (sifat) yang memerhatikan dan mengutamakan kepentingan orang lain di atas segalanya. Dalam altruisme terdapat rasa cinta yang tidak terbatas kepada sesama tanpa melihat latar belakang kehidupan. Altruisme bisa diartikan sebagai sikap manusia yang mungkin bersifat naluriah, berupa dorongan atau

\footnotetext{
${ }^{2}$ Ahmad Taufik Nasution, Melejitkan SQ Dengan Prinsip 99 Asmaul Husna: Merengkuh Puncak Kebahagiaan Dan Kesuksesan Hidup (Jakarta: PT. Gramedia Pustaka Utama, 2009). 4-5
} 
motivasi untuk berbuat baik kepada orang lain. Sikap berbuat baik kepada orang lain adalah salah satu cerminan dari pribadi altruis yang jarang sekali ditemukan dalam kehidupan ini.

Pribadi altruis adalah karakter seseorang yang lebih mengutamakan kepentingan orang lain dibandingkan dengan kepentingan diri sendiri. Kepentingan orang lain yang membutuhkan pertolongan lebih utama dibandingkan dengan kepentingan yang bersifat pribadi. Harus disadari dalam diri manusia, terdapat dua motif yang saling bertentangan ketika hendak memberikan bantuan kemanusiaan, yakni altruis dan egois. Perilaku menolong yang bersifat egois bukan semata-semata untuk menolong, tapi ia ingin memanfaatkan orang yang ditolong. Sementara perilaku yang altruis adalah benar-benar murni hanya untuk menolang tanpa ada harapan untuk memperoleh imbalan atau berusaha untuk memanfaatkan orang yang ditolong. ${ }^{3}$

Dalam psikologi modern, mengasihi sesama berarti memiliki kesadaran yang mendalam mengenai apa yang tengah diderita oleh orang lain. Altruisme adalah sebuah sikap yang menunjukkan bahwa kita semua memiliki keinginan kodrati untuk membantu dan memberikan pertolongan kepada orang lain. Sadar akan penderitaan, baik penderitaan kita sendiri atau penderitaan orang lain, sesungguhnya membantu kita menjadi pribadi yang dewasa. Sikap ini bisa menyentuh hati kita untuk berbagi kebahagiaan dengan orang, meskipun memiliki latar belakang yang berbeda dengan kita.

Fuad Nashori, seorang pakar psikologi Islam, memahami bahwa suatu tindakan dapat disebut altruisme apabila memenuhi tiga kriteria. Pertama, tindakan tersebut bukan untuk kepentingan diri sendiri. Ketika orang memberikan tindakan altruisme boleh jadi ia mengambil risiko yang berat bagi si pelaku, namun ia tidak mengharapkan imbalan materi, nama kepercayaan, dan tidak pula untuk menghindari kecaman orang lain. Kedua, tindakan tersebut dilakukan secara suka rela. Suatu tindakan disebut altruisme apabila dilakukan atas dasar keikhlasan bukan karena paksaan. Ketiga, hasilnya baik bagi yang menolong maupun yang ditolong. Tindakan altruistik sesuai dengan kebutuhan orang yang ditolong dan si pelaku memperoleh internal reward atas tindakannnya. ${ }^{4}$

\footnotetext{
${ }^{3}$ Desmita, Psikologi Perkembangan (Bandung: Remaja Rosdakarya, 2008).131

${ }^{4}$ Fuad Nashori, Psikologi Sosial Islami (Jakarta: PT. Refika Aditama, 2008).36
} 
Orang yang melepaskan dari semua kepentingan ketika hendak menolong orang lain adalah termasuk pribadi yang altruis. Ini karena, kepentingan diri sendiri bukan lagi sebagai tujuan utama untuk memperoleh balasan atau kekayaan dengan cara memanfaatkan kebaikan orang lain. Seringkali kita melakukan sesuatu bukan karena didorong oleh hati nurani, tetapi semata-mata dipengaruhi oleh kepentingan diri atau kelompok. Akibatnya, kita hanya mau melakukan sesuatu apabila hal itu dapat memberi manfaat bagi diri sendiri. ${ }^{5}$

Perilaku altruistik ini merupakan kebalikan langsung dari sifat egoistik dan individualistik, yang selalu mementingkan diri sendiri dalam melakukan suatu pekerjaan tertentu. Kesadaran untuk menolong orang lain dan berbagi dengan sesama belum melekat dalam jiwa orang yang individualistik. Akibatnya, perilakunya selalu diwarnai oleh bagaimana kepentingan sendiri menjadi prioritas dan jarang sekali memikirkan kepentingan orang lain, atau sekadar memberikan uluran tangan kepada orang-orang yang membutuhkan bantuan.

Sikap altruisme dalam konteks modern tampaknya menjadi sesuatu yang sangat sulit untuk dijumpai. Ikatan persaudaraan antara sesama manusia bukan lagi merupakan sesuatu yang penting untuk diperkuat. Semangat untuk bertindak secara kolektif atau peduli terhadap sesama kian hari terkikis oleh nilai-nilai sektarianisme dan primordialisme. Sikap kepedulian dan semangat berbagi menjadi sesuatu yang sangat langka dalam konteks modern sekarang ini. Tampaknya sikap altruisme perlu ditanamkan sebagai sebuah sikap yang tidak lagi mendahulukan kepentingan diri sendiri, tetapi lebih punya gairah untuk bersikap empatik terhadap orang lain. ${ }^{6}$

Perilaku altruistik adalah sebuah karakter dasar bagi seorang muslim sejati yang bisa membedakan dengan orang yang cenderung individualistis. Karakter yang melekat dalam diri seorang altruis adalah mampu mengabaikan egonya yang berlebihan dan berusaha membantu orang lain dengan segenap kemampuan yang dimilikinya. Sikap altruisme inilah yang pernah dicontohkan kaum Anshar terhadap kaum Muhajirin yang rela memberikan tempat tinggal sebagai persinggahan sementara. Dengan sikap altruistik yang melekat dalam diri kaum Anshar, para pendatang yang berasal dari Mekkah memperoleh tempat

\footnotetext{
${ }^{5}$ Ahmad Taufik Nasution, Melejitkan SQ Dengan Prinsip 99 Asmaul Husna: Merengkuh Puncak Kebahagiaan Dan Kesuksesan Hidup.93

${ }^{6}$ David G Myer, Psikologi Sosial (Jakarta: Salemba Humanika, 2012).187
} 
yang layak dan bisa tinggal dengan tenang tanpa adanya gangguan dari kafir Quraish. Apa yang dilakukan kaum Anshar adalah bentuk implementasi dari sikap altruistik yang didorong oleh semangat untuk mengesampingkan kepentingan pribadi demi memberikan pertolongan terhadap penderitaan orang lain yang sangat membutuhkan. ${ }^{7}$

\section{Terapi Syukur}

Dimensi psikologis menjadi bagian penting dari perilaku syukur yang merupakan salah satu dimensi yang bisa memengaruhi motivasi seseorang untuk membiasakan diri bersyukur kepada Tuhan. Dimensi psikologis yang tampak dalam perilaku syukur adalah menyangkut mental manusia dalam menggerakkan hatinya untuk berbagi kepada sesama setelah memperoleh kenikmatan dari Tuhan. ${ }^{8}$ Mental menjadi landasan bagi pemikiran manusia untuk memenuhi kebutuhan yang belum terjangkau sehingga memengaruhi setiap keputusan dan langkah yang akan diambil. Perilaku syukur merupakan persoalan mental yang bisa dibina sejak seseorang masih dalam pengawasan orangtua.

Jika mental bersyukur seseorang sudah dilatih sejak usia dini, perilaku positif ini bisa terpatri secara integral dalam menjalani kehidupan ini. Mental bersyukur bukanlah sesuatu yang berdiri sendiri atau muncul tanpa ada proses yang menyertainya, melainkan melalui proses latihan yang tidak mudah sebagaimana yang dibayangkan. Dalam dimensi psikologis, perilaku syukur membutuhkan latihan secara terus-menerus dalam setiap langkah yang dijalani manusia. Jika latihan syukur dibiasakan setiap hari, maka mental positif ini akan memberikan dampak yang besar bagi keperibadian manusia itu sendiri. Ini karena, mental bersyukur bisa menjadi karakter yang melekat dalam setiap individu yang merasa dirinya butuh terhadap sang pemberi nikmat di dunia ini.

Dimensi psikologis yang juga terdapat dalam perilaku syukur adalah dimensi emosional. Dimensi psikologis ini terkait dengan ego atau sifat ke-aku-an yang melekat dalam diri manusia dan menjadi pemicu lahirnya ambisi yang berlebihan. Struktur ego yang melekat dalam setiap diri manusia bisa membawa malapetaka bagi masa depan jika keinginan yang direncanakan tidak terpenuhi. Dalam konteks kekinian, banyak sekali

\footnotetext{
${ }^{7}$ Aliah B Hasan and Purwakania, Psikologi Perkembangan Islami (Menyingkap Rentang Kehidupan Manusia Dari Prakelahiran Hingga Pasca Kematian) (Jakarta: Raja Grafindo Persada, 2006).265

${ }^{8}$ David Carr, Perspective on Gratitude: An Interdisciplinary Approach. New York: Routledge. (New York: Routledge, 2016).10
} 
manusia yang terjebak dengan egonya karena selalu tidak puas dengan nikmat dan karunia Tuhan yang diberikan. Ketika itulah ego mengendalikan emosi dan perasaan untuk menolak kebersyukuran sebagai perilaku yang bisa mendorong manusia agar tidak mudah menyalahkan atau mengeluh dengan karuniaTuhan.

Permasalahan yang muncul dalam dimensi syukur adalah menyangkut tentang ketidakmampuan manusia dalam menyikapi nikmat Tuhan sebagai sebuah pemberian yang harus disyukuri. Di tengah kemajuan teknologi modern, jiwa manusia untuk mencapai zona syukur seringkali dikalahkan oleh kesombongan diri yang merasa dirinya tidak butuh pada Tuhan. Sifat ke-aku-an atau ego yang mewarnai jiwa manusia ternyata mampu mengalahkan hati nurani yang paling dalam. Tidak heran bila sifat ke-aku-an atau ego menjadi sebuah penghalang bagi manusia untuk menjadi pribadi yang rendah hati dan ikhlas dalam menerima semua ketentuan Allah.

\section{Teknik Bersyukur}

Pertama, bersyukur dengan lisan. Dalam psikologi qur'ani, bersyukur dengan lisan adalah mengucapkan secara terbuka (terang) kalimat alhamdulillah (segala puji bagi Allah) sebagai ungkapan rasa terima kasih yang tidak terhingga kepada Allah yang telah memberikan nikmat luar biasa. Ungkapan Alhamdulillah merupakan ungkapan syukur yang sangat penting bagi setiap muslim untuk menggerakkan hati dan anggota tubuh agar senantiasa menjaga hidup dengan penuh kesyukuran. Di dalam al-Qur'an, kata Alhamdulillah (segala puji bagi Allah) sering disebut di awal dan menjadi bagian dari ekspresi bahasa yang sangat penting. Ekspresi bahasa Alhamdulillah merupakan kelaziman untuk mengakui akan kenikmatan yang Allah berikan sehingga kalimat tersebut menetapkan (meng-set) tanda awal pada seluruh al-Qur'an dan memberikan pesan penting untuk mengungkapkan rasa syukur melalui bahasa lisan. ${ }^{9}$

Dalam pandangan William Chittick dan Sachiko Murata ${ }^{10}$, frase Alhamdulillah (segala puji bagi Allah), bukan merupakan satu seruan, meskipun orang mungkin sering menggunakannya. Hal tersebut tidak ekuivalen dengan kalimat bahasa Inggris "praise be to God" (segala puji untuk Tuhan), yang diucapkan pada beberapa kesempatan tertentu. Nabi sendiri mengekspresikan pandangan bahwa segala sesuatu yang baik berasal dari Allah.

\footnotetext{
${ }^{9}$ Sachiko Murata and William Chittick, The Vision of Islam (Yogyakarta: Suluh Press, 2005).55

${ }^{10}$ Ibid.55
} 
Buktinya dalam doa atau pujian pendek beliau, “kebaikan, semuanya, berada di tangan-Mu, dan keburukan tidak akan kembali kepada Engkau."

Dengan menyebut alhamdulillah pada setiap kesempatan, kita sudah menunjukkan pengakuan secara lisan akan kebesaran karunia Allah yang sangat melimpah di muka bumi. Jika seorang hamba menyebut-nyebutnya, maka akan teringat kepada pemberinya dan mengakui kelemahan dirinya dan dengan sendirinya ia akan tunduk kepada Allah, memujiNya, bersyukur kepada-Nya, dan banyak mengingat-Nya dengan berbagai macam dzikir, sebab dzikir merupakan pangkalnya syukur. Orang yang tidak mengingat Allah berarti tidak bersyukur kepada-Nya. ${ }^{11}$

Kedua, bersyukur dengan hati. Setelah bersyukur dengan lisan, barulah manusia bisa bersyukur dengan hati yang menjadi pengontrol setiap yang diucapkan setiap harinya. Teknik bersyukur dengan hati merupakan salah satu cara bagi seorang muslim untuk memantapkan keyakinan akan karunia Allah yang sangat besar di muka bumi ini. Bersyukur dengan hati mencerminkan bahwa manusia mengakui dan menyadari sepenuhnya segala nikmat yang diperoleh berasal dariAllah dan tiada seseorang pun selain Allah yang dapat memberika nikmat yang tidak terbatas ini.

Syukur adalah sarana untuk memanfaatkan dan memelihara karunianya. Hati yang bersyukur dapat memperkuat dan memantapkan kebaikan yang sudah dilakukan serta akan menghasilkan kebaikan yang belum ada. Orang awam hanya bersyukur bila memperoleh rezeki material. Sementara orang-orang yang memperoleh pencerahan batin selalu bersyukur, baik ketika memperoleh nikmat atau pun tidak. Orang yang telah memperoleh nur ilahi tidak memedulikan nikmat maupun penderitaan, karena mereka melihat karunia dan rahmat Allah di balik semua penampakan dan pengalaman. ${ }^{12}$

Ketiga, bersyukur dengan perbuatan. Teknik bersyukur selanjutnya dalam psikologi qur'ani adalah dengan perbuatan melalui anggota badan yang bisa dimanfaatkan untuk mengelola berbagai kenikmatan Allah di jalan yang benar. Syukur dengan anggota badan meniscayakan apa saja bentuk amalan atau pekerjaan kebajikan yang meliputi seluruh anggota badan untuk dipergunakan sebagaimana yang telah diajarkan dalam ajaran Islam.

${ }^{11}$ J. Spencer Trimingham, The Sufi Orders in Islam (London \& Oxford: Oxford University Press, 1973). 145

${ }^{12}$ Syekh Fadhalla, Al-Hikam: 264 Hikmah dan Renungan Spiritual Harian Ibn Athaillah (Jakarta: Serambi, 2013).64 
Teknik bersyukur dengan perbuatan memang harus melibatkan anggota badan dalam mengekspresikan bentuk ketaatan dan pengabdian secara total kepada Allah. Dalam bersyukur, kita perlu memanfaatkan semua karunia Allah yang sangat besar ini untuk kepentingan ibadah dan amal kebajikan. Syukur dengan perbuatan adalah dengan memanfaatkan seluruh anugerah yang diperoleh untuk merenungkan tujuan penganugerahannya serta menuntut penerima nikmat untuk merenungkan tujuan dianugerahkannya nikmat tersebut oleh Allah. Perenungan terhadap tujuan berbagai kenikmatan yang telah dilimpahkan Allah merupakan langkah primordial bagi setiap muslim untuk memanfaatkan segenap daya dan kekuatan untuk kepentingan yang lebih luas, terutama untuk kemaslahatan umat manusia secara keseluruhan. ${ }^{13}$

Secara sederhana, teknik bersyukur dengan perbuatan adalah menggunakan anggota tubuh untuk melakukan hal-hal positif yang membawa kebaikan dan keselamatan di dunia maupun di akhirat. Banyak sekali contoh yang bisa dipraktikkan dalam kehidupan seharihari terkait dengan teknik bersyukur dengan perbuatan atau melalui anggota badan. Semisal, jika memperoleh karunia berupa harta benda, maka kita harus mempergunakan harta itu sesuai dengan ajaran agama. Jika nikmat yang diperolehnya berupa ilmu pengetahuan atau kecerdasan intelektual, maka kita perlu memanfaatkan ilmu itu untuk kepentingan keselamatan, kebahagiaan, dan kesejahteraan umat manusia.

Dari sini bisa dipahami bahwa bentuk syukur dengan anggota badan adalah mempergunakan nikmat Allah dalam hal ketaatan dan tidak menggunakannya dalam hal kemaksiatan. Bentuk syukur mempunyai dua mata yang bisa melihat adalah dengan menutupi aib seorang muslim yang pernah ia lihat. ${ }^{14}$ Dalam contoh yang lain, adalah mensyukuri nikmat mata dengan tidak mempergunakannya untuk melihat hal-hal yang berbau maksiat. Apalagi sekarang dunia teknologi semakin canggih dan perkembangan internet sudah mewabah ke berbagai pelosok desa sehingga sangat mudah bagi siapa saja untuk melihat tontonan yang berbau pornografi dan lain sebagainya.

Teknik bersyukur dalam psikologi qur'ani dan psikologi positif memang memiliki perbedaan dari sisi sumber ajaran. Namun, hakikatnya tidak jauh berbeda dan memiliki

\footnotetext{
${ }^{13}$ M Qurais Shihab, Wawasan Al-Qur'an: Tafsir Maudhu'i Atas Pelbagai Persoalan Umat (Bandung: Mizan, 1996).221

${ }^{14}$ Ulya Uli Ubaid, Sabar Dan Syukur Gerbang Kebahagiaan Dunia Dan Akhirat (Jakarta: Bumi Aksara, 2014). 172
} 
tujuan yang sama untuk berterimakasih atas apa yang telah diperoleh, baik karena pemberian orang lain atau secara khusus berterimakasih kepada Tuhan yang telah mengabulkan doa dan permohonan seseorang. Teknik bersyukur dalam psikologi modern dapat dilakukan dengan dua cara yang sangat sederhana, yaitu secara personal dan transpersonal.

Pertama, bersyukur secara personal. Teknik pertama ini adalah sebuah cara yang bisa dipraktikkan ketika kita menerima hadiah dari orang lain. Teknik bersyukur ini memang berangkat dari kesadaran diri yang merasakan sebuah bantuan atau pertolongan dari orang lain. Orang yang berterimakasih terhadap adanya bantuan dari orang lain merupakan pribadi yang tidak egois dengan situasi atau kondisi yang membelenggu diri. Teknik bersyukur ini sama sekali tidak berat untuk dilakukan, namun seringkali mengalami banyak hambatan dan tantangan dari orang yang bersangkutan. Ketika memperoleh bantuan dalam bentuk materi maupun tenaga, kita tinggal melangkah diri untuk mengucapkan kata terimakasih secara tulus.

Bersyukur dalam psikologi positif adalah sebuah bentuk pengakuan atas kebaikan orang lain yang telah memberikan bantuan atau kontribusi penting dalam hidup Anda. ${ }^{15}$ Pengakuan atas kebaikan orang lain adalah bentuk syukur yang harus Anda ingat selalu, karena berkaitan dengan kepentingan orang lain. Artinya, Anda tetap mengingat kebaikan yang pernah orang lain lakukan dalam hidup Anda sehingga tetap menjadi kenangan yang tidak terlupakan.

Kedua, bersyukur secara transpersonal. Teknik bersyukur selanjutnya yang bisa kita lakukan adalah secara transpersonal. Bersyukur secara transpersonal merupakan sebuah ungkapan terimakasih kepada Tuhan yang telah memberikan banyak karunia di dunia ini. Pribadi yang cenderung bersyukur adalah mereka yang meyakini akan kekuasaan Tuhan dalam melimpahkan rezeki ke muka bumi. Pribadi yang bersyukur juga akan senantiasa merefleksikan kehidupan ini dengan penuh kelapangan dan kesyahduan, karena Tuhan dianggap sebagai pemberi segalanya bagi kehidupan umat manusia.

Bersyukur secara transpersonal merupakan bentuk syukur yang sangat mendalam dan tidak sekadar pengakuan atas kekuasaan Tuhan yang memberikan kenikmatan hidup di

${ }^{15}$ Robert A Emmons, Thanks! How The New Science of Gratitute Can Make You Happier. 5-7 
dunia ini. Bentuk syukur ini sudah melampaui diri manusia dan sama sekali tidak terfokus pada kebaikan manusia, melainkan menjadikan Tuhan sebagai sumber dari segala sumber yang memancarkan cahaya kebaikan dan kenikmatan kepada manusia.

\section{Latihan Bersyukur}

Meskipun perilaku syukur cenderung mudah diucapkan dalam setiap kesempatan, namun dalam praktiknya seringkali mengalami kesulitan dan mendapatkan banyak hambatan. Dari sini dibutuhkan latihan secara konsisten dan terus-menerus untuk menjadikan syukur sebagai perilaku yang bernilai ibadah dan bermanfaat bagi keberlangsungan hidup di masa yang akan datang. Latihan bersyukur bukan bermaksud untuk menjadikan setiap orang sebagai pribadi yang sombong atau bersikap jumawa dengan apa yang dipraktikkan, melainkan sebagai langkah awal untuk membiasakan diri menjadi pribadi yang tidak lupa dengan sang pencipta yang telah memberikan nafas kehidupan di dunia ini.

Di dalam psikologi qur'ani, hakikat syukur sesungguhnya lebih ditunjukkan kepada Allah sebagai sang pemberi nikmat kepada setiap manusia. Kebersyukuran adalah bentuk pengakuan terhadap nikmat yang dikaruniakan Allah, yang disertai dengan ketaatan dalam mempergunakan semua nikmat itu di jalan-Nya. Rasa syukur adalah salah satu tanda orang beriman sehingga harus mengakui akan kebesaran karunia Allah yang tidak terbatas di muka bumi. Maka barang siapa yang bersyukur, berarti ia menyadari secara penuh akan hubungan personal antara hamba dan sang pencipta. ${ }^{16}$

Dalam psikologi modern, latihan bersyukur cakupannya lebih luas dan lebih ditunjukkan untuk mengingatkan akan peran penting orang lain dalam setiap kesuksesan dan kebahagiaan yang diraih oleh seseorang. Bersyukur bukan berarti ingin menunjukkan bahwa kita adalah orang yang paling dermawan dalam mengeluarkan bantuan kepada orang yang membutuhkan, lebih daripada itu adalah agar kita tidak lupa diri dengan kekuatan Tuhan yang telah memberikan jalan atau garis kehidupan yang lebih baik dari orang lain.

Pertama, ucapkan alhamdulilah setiap waktu. Latihan bersyukur dalam Islam ini memang menjadi langkah awal bagi setiap muslim untuk membiasakan diri untuk

${ }^{16}$ M.I El-Firdausy, Rahasia Kedahsyatan Syukur (Semarang: One Book, 2008).23 
mengenal dan menikmati karunia Allah yang tidak pernah terbatas di muka bumi. Setiap kali memperoleh nikmat dari Allah, tariklah nafas secara perlahan-lahan kemudian katakan dengan penuh penghayatan, "Alhamdulillah" (Terimakasih Ya Allah). Kalimat ini memang terkesan sangat sederhana dan mudah diucapkan, namun kedahsyatannya sangat luar biasa. Ucapan Alhamdulillah memang menjadi anjuran Nabi yang sangat penting bagi setiap muslim yang merasa dirinya mengabdi kepada Allah. Kalimat Alhamdulillah pun menjadi salah satu ucapan yang sangat familiar dan menjadi kekuatan utama bagi seorang muslim untuk menunjukkan akan kekuasaan Allah.

Kedua, membuat sistem pengingat. Latihan rasa bersyukur tidak mudah sebagaimana yang dibayangkan. Perilaku syukur bukan sekadar semangat dalam ucapan, melainkan harus diimplementasikan dalam setiap tindakan setiap harinya. Kebiasaan mengucapkan kata syukur memang menjadi langkah awal bagi setiap manusia untuk merasakan kedahsyatan pengaruh syukur, tetapi harus disertai dengan kecerdasan dalam bersikap disiplin atau konsisten dalam menjalankan perilaku syukur setiap hari. Secara sederhana, hal yang dapat kita lakukan adalah dengan membuat sistem pengingat/alarm dengan cara menuliskan sesuatu yang kecil yang semestinya disyukuri setiap hari.

Kedua, menuliskan catatan syukur setiap hari. Latihan syukur dengan menuliskan beberapa catatan penting setiap hari merupakan cara yang mudah dilakukan. Hal-hal yang ingin disyukuri setiap harinya, sebaiknya dibuatkan sebuah catatan di buku kecil yang bisa menampung kebaikan yang telah dilakukan. Aktivitas membuat catatan syukur bisa kita lakukan menjelang tidur atau di pagi hari yang sangat segar. Semisal, dalam satu hari kita menyelesaikan pekerjaan rumah (menyapu, menyiram bunga, atau mengepel lantai), maka kita tinggal mengucapkan rasa syukur itu sebagai bentuk karunia dalam menyelesaikan semua pekerjaan dengan baik.

Ketiga, menciptakan gelombang syukur di alam terbuka. Dalam latihan syukur ini, setiap orang bisa melakukannya di mana saja dan kapan saja, termasuk bersyukur di alam terbuka. Menciptakan gelombang syukur di alam terbuka sesungguhnya merupakan cara efektif agar tidak mudah lupa dengan apa yang diberikan Tuhan. Di alam terbuka setiap orang bisa merenungkan dan mengambil pelajaran dari semua kemurahan dan kasih sayang Tuhan yang menciptakan keindahan dunia beserta dengan isinya. Kebiasaan menciptakan 
gelombang syukur di alam terbuka pada gilirannya bisa membuat kita semua semakin termotivasi untuk memanfaatkan semua karunia Tuhan dengan penuh keikhlasan.

Keempat, lakukan meditasi secara simultan. Sebelum memulai meditasi, dibutuhkan sikap rileks dan tidak mudah tegang dengan apa yang dipikirkan. Ketika perasaan kita sudah rileks, maka kita bisa memulai kegiatan meditasi dengan penuh keheningan dan keintiman. Dalam melakukan meditasi, kita dituntut untuk menghilangkan semua keruwetan atau pun permasalahan hidup yang menimpa dalam kehidupan sehari-hari. Ini karena, meditasi membutuhkan konsentrasi tingkat tinggi yang menyelaraskan pikiran dan perasaan dalam satu kesatuan yang tidak terpisahkan. ${ }^{17}$

Meditasi merupakan sebuah teknik sufistik untuk meraih kebersatuan dengan Tuhan. Ketika menjalankan meditasi, hati dan pikiran sebisa mungkin sudah terbebas dari belenggu kemunafikan maupun kesombongan. Ini karena, meditasi termasuk pengalaman spiritual yang menuntut kerendahhatiaan dalam menerima semua ketentuan Tuhan sebagai sang pemberi kenikmatan bagi manusia di dunia ini. Meditasi merupakan olah rohani dalam ajaran agama yang dianggap mampu membuka kesadaran hati (the heart consciousness) dan mengheningkan pikiran dari segala kegalauan yang menghantui. Melalui meditasi, pengalaman sufistik seseorang akan semakin meningkat seiring dengan ilham yang diperoleh dari sang pencipta. Meditasi bukan semata-mata latihan duduk dengan diam, tetapi dalam meditasi jiwa harus diisi dengan pancaran cahaya, kehidupan yang baru, dengan inspirasi, dan kesabaran. Meditasi sekarang merupakan alternatif untuk mengatasi berbagai persoalan yang dihadapi manusia modern. Maka berkembanglah beberapa penelitian tentang pengaruh meditasi terhadap gelombang-gelombang otak sebagaimana yang berkembang di negara timur. ${ }^{18}$

\section{Perspektif Psikologi Qur'ani tentang Terapi Syukur dalam Membentuk Pribadi Altruis}

Makna terapi syukur dalam perspektif psikologi qur'ani merupakan konsep penting yang memengaruhi praktik kesufian di dunia muslim. Sebagai salah satu maqam sufi, konsep syukur dipandang penting dalam menapaki tingkatan tertinggi demi meraih kebahagiaan sejati dan kesempurnaan iman ketika bertemu langsung dengan Allah. Maka

\footnotetext{
${ }^{17}$ Satriyo, Meditasi Syukur 20 Menit (Yogyakarta: Kanisius, 2009). 15

${ }^{18}$ Charles T Tart, Altered States of Consciousness (New York: Doubleday \& Company., 1972).23
} 
dipandang perlu bagi kita semua untuk mengetahui makna syukur dalam perspektif psikologi qur'ani yang memuat pesan-pesan spiritual menuju cahaya ilahi yang menjadi tujuan utama dari kehidupan umat manusia.

Perilaku syukur termasuk salah satu tingkatan tertinggi dalam dunia kesufiaan, karena mencerminkan karakter luhur dari seorang muslim yang taat menjalankan perintah Allah dengan penuh ketulusan dan keikhlasan. Allah sendiri mengatakan bahwa tidak menjamin kenaikan tingkat (maqam) kecuali dengan melewati zona syukur yang merupakan salah satu tingkatan tertinggi dalam dunia kesufiaan. Hal ini menunjukkan bahwa syukur merupakan tingkat maqam yang terbaik dan laku ketaatan yang terafdhal, sebab ia memuat puncak keceriaan di hadapan Allah dan memiliki konsekwensi cinta kepada Allah.

Tidak dapat diragukan lagi bahwa maqam syukur lebih tinggi dibandingkan dengan maqam sabar, sebab orang yang bersyukur justru melihat anugerah (karunia) dalam lipatan cobaan (mihnah) sehingga ia pun menerima bencana dengan wajah ceria. Seseorang tidak bisa disebut benar-benar bersyukur sampa ia bersyukur dalam keadaan suka maupun duka. Ia tidak bisa disebut syukur dalam kondisi sempit sampai ia melihatnya sebagai kondisi lapang berupa kebahagiaan, karena kandungan yang dihadapinya sewaktu dalam kondisi duka berupa keterbukaan hati (al-futuhat al-qalbiyah) dan anugerah-anugerah laduniyah (almawahib al-laduniyah) sehingga bencana bisa saja berupa nikmat yang tak terduga. ${ }^{19}$

Istilah syukur dalam psikologi qur'ani memang menjadi salah satu kata kunci yang sering disebut sebagai gambaran bagi manusia bahwa maqam kesufian ini merupakan perilaku positif yang sangat dicintai oleh Allah. Menurut penelitian para mufassir, kata-kata syukur (شُكُْر) dalam berbagai bentuknya ditemukan tidak kurang dari 75 kali dalam alQur'an. Dalam beberapa ayat, syukur tidak sekadar dipakai dalam rangka perbuatan manusia dalam mensyukuri segala nikmat Allah, tetapi juga dalam rangka mengungkapkan sikap Allah terhadap apa yang dilakukan manusia. Dari sini kata syakir dalam bentuk isim

\footnotetext{
${ }^{19}$ Muhammad Khalid Tsabit, Quantum Ridha: I'tibar Kesejukan Hati, Kemuliaan Pribadi Terhadap Qadha Ilahi (Jakarta: Amzah, 2009). 208
} 
fa'il atau kata syakur dalam bentuk sighat mubalaghah tidak hanya diperuntukkan kepada manusia, melainkan juga kepada Allah..$^{20}$

Dalam al-Qur'an, terdapat dua ayat yang menjelaskan bahwa Allah sebagai syakir dan ada empat ayat yang menyebut Allah sebagai syakur. Syukur manusia kepada Allah dalam pengertian terminologis berarti menggunakan nikmat Allah pada hal-hal yang menjadi tujuan diciptakannya nikmat itu oleh Allah (sarf niamih funa khuliqat lah). Hal ini berbeda dengan syukurnya Allah yang sangat sangat Maha Pemurah bagi hamba-Nya. Kata syakur sebagai sifat Allah adalah Dia yang memberikan balasan pahala kepada orang-orang yang melakukan kebaikan dan juga menanugerahkan kenikmatan yang tidak terbatas di alam semesta ini. Tidak heran bila istilah syukur dalam al-Qur'an menempati posisi yang sangat mulia, karena sering dijadikan alasan penciptaan alam semesta ini. Penyebutan istilah syukur dalam al-qur'an, meniscayakan setiap manusia untuk tidak lupa dengan segala nikmat Allah yang melimpah di dunia ini, sehingga orang yang dengan sengaja melupakan limpahan rahmat Tuhan sering disebut dengan kufur (ingkar).

Sementara kata syukuran (شُكُوْرًا) sendiri hanya disebutkan dua kali dalam al-Qur'an, yakni pada surat al-Furqan ayat 62 dan surat al-Insan ayat 9.21 Kata syukuran yang pertama digunakan ketika Allah memberikan ilustrasi tentang proses penciptaan siang dan malam yang berjalan secara bergantian dan tidak pernah berbenturan. Situasi silih berganti menjadi sebuah cerminan bagi orang-orang yang berupaya mengambil hikmah dari semua penciptaan alam semesta ini dan bersyukur atas nikmat yang diberikan Allah. Pergantian siang dan malam merupakan salah satu bentuk kekuasaan Allah yang wajib disyukuri oleh setiap umat manusia, karena kita semua bisa menikmati keindahan dan keagungan alam semesta.

Dalam surat al-Insan, Allah memberikan sebuah ilustrasi tentang orang-orang yang melakukan suatu amal kebaikan dan memberikan makan kepada orang-orang fakir dan miskin, yang hanya mengharapkan keridhaan sebagai tujuan utama. Apa yang mereka lakukan dalam bentuk kebaikan dengan memberi makan fakir miskin menjadi gambaran orang-orang yang selalu bersyukur dan tidak lupa dengan sesama. Memberikan sesuatu yang bermanfaat bagi fakir miskin dengan tanpa mengharapkan balasan atau menanti

\footnotetext{
${ }^{20}$ Abd al-Baqi and Muhammad Fuad, "Al-Mu'jam Al-Mufahras Li Al-Fadl Al-Qur'an," Mesir: Dar alFikri (1981).386

${ }^{21}$ Ibid.387
} 
ucapan terimakasih merupakan sebuah sifat terpuji dan mulia di hadapan Allah. Apalagi, perilaku syukur menjadi salah satu sifat Allah yang harus diteladani oleh setiap hambanya.

Di dalam psikologi qur'ani, kata-kata syukur memang menjadi term yang sangat familiar karena menjadi salah satu maqam kesufian untuk lebih dekat dengan Allah. Para sufi yang menjalani hidup dengan rasa syukur adalah orang-orang yang selalu memuji dan menebarkan kebaikan terhadap sesama tanpa mengharapkan balasan atau limpahan rahmat yang lebih dari Allah. Gambaran para sufi adalah mereka tetap bersyukur meskipun dalam keadaan menderita dan tidak memiliki kekayaan untuk berbagi kepada sesama. Para sufi mempraktikkan syukur dengan cara mengucapkan kalimat Alhamdulillah dalam lisan dan hati serta senantiasa mempergunakan nikmat Allah dengan sebaik-baiknya.

Pemaknaan syukur juga bisa diambil dari fi'il madhi-nya syakara yang merupakan lawan dari kata kafara. Makna dari kata ini adalah bahwa syukur adalah "menampakkan nikmat" kepada siapa pun tanpa terkecuali. ${ }^{22}$ Hal ini berbeda dengan orang-orang kufur yang selalu berusaha untuk menyembunyikan nikmat dan bahkan mengingkari asal-muasal dari turunnya nikmat tersebut. Arti menampakkan nikmat bisa dipahami bahwa kita harus mempergunakan nikmat sesuai dengan apa yang sudah diperintahkan oleh sang pemberi nikmat, yakni Allah. Jika kita menggunakan nikmat sesuai dengan apa yang dikehendaki sang pencipta, berarti kita selalu berupaya menjadikan nikmat itu bermanfaat bagi orang lain. Limpahan rahmat yang tidak terbatas ini meniscayakan hambanya untuk selalu ingat dan tidak merasa dirinya paling hebat di dunia. ${ }^{23}$

Dalam psikologi qur'ani, pemaknaan syukur lebih terkait dengan bagaimana setiap muslim harus membuka diri dan menampakkan segala kenikmatan tanpa ada upaya untuk menyembunyikan demi kepentingan pribadi. Membuka atau menampakkan nikmat Allah bisa dilakukan dengan memberi sebagian rezeki yang diperoleh tanpa merasa akan terkurangi. Bagi siapa pun yang menyembunyikan nikmat Allah, berarti ia disebut dengan kikir dan termasuk juga bagian dari kufur. Jadi, hakikat syukur adalah menampakkan

\footnotetext{
${ }^{22}$ Amir An-Najar, Psikoterapi Sufistik Dalam Kehidupan Modern (Bandung: PT. Mizan Publika, 2004). 90

${ }^{23}$ M Qurais Shihab, Wawasan Al-Qur'an: Tafsir Maudhu'i Atas Pelbagai Persoalan Umat.216
} 
nikmat yang Allah karuniakan dengan cara mempergunakannya di jalan yang dikehendaki oleh Allah. ${ }^{24}$

Dalam pengertian lain, syukur adalah bentuk pengakuan terhadap nikmat yang dilimpahkan oleh Allah dengan disertai ketundukan dan mempergunakan nikmat tersebut sesuai dengan apa yang sudah diperintahkan-Nya. ${ }^{25}$ Pengakuan terhadap nikmat Allah merupakan cerminan dari pribadi muslim yang benar-benar meyakini akan kekuasaan-Nya yang disertai dengan ungkapan alhamdulillah dalam setiap kesempatan. Pengakuan dengan hati dan disertai dengan ungkapan alhamdulillah menjadi salah satu faktor penting akan tercapainya kebiasaan dalam mensyukuri segala nikmat yang melimpah di muka bumi ini.

Dari perspektif psikologi qur'ani, kita bisa mempertebal keyakinan bahwa Allah merupakan dzat yang Maha Penyayang bagi hamba-hamba-Nya yang selalu bersyukur dan memberikan kesempatan untuk selalu memperbaiki perilaku kesehariaan yang bertentangan dengan rasa syukur. Jika syukur dijadikan terapi oleh segenap umat Islam, maka setiap manusia akan memiliki kesadaran akan pentingnya berbagi pada sesama.

Dari situasi inilah, sikap altruisme perlu ditumbuhkan dalam setiap pribadi manusia yang beriman, karena Islam tidak hanya mengajarkan untuk membangun hubungan baik terhadap sang pencipta (hablum minallah), tapi juga hubungan terhadap sesama manusia. Salah satu kekuatan atau energi yang bisa membangkitkan semangat peduli dan empati kepada sesama adalah dengan membiasakan pola hidup syukur sebagai wawasan kesufian yang sangat tinggi nilainya di hadapan Allah. Mengapa syukur dianggap memiliki peran penting dalam membangkitkan semangat kepedulian terhadap sesama? Ini karena, syukur merupakan sebuah energi dalam diri manusia yang tidak hanya berdimensi teologis, tapi juga bisa mencakup pada dimensi sosiologis.

Kedahsyatan energi syukur dalam psikologi qur'ani diyakini dapat mengubah perilaku hedonis dan konsumeris yang mewarnai dinamika kehidupan masyarakat secara luas. Beberapa peneliti sudah melakukan kajian secara mendalam mengenai pengaruh syukur dalam berbagai aspek kehidupan, semisal bisa memberikan perasaan tenang dan damai dalam menghadapi segala tantangan hidup. Dimensi syukur memiliki kekuatan yang

24 Aura Husna, Kaya Dengan Bersyukur: Menemukan Makna Sejati Bahagia Dan Sejahtera Dengan Mensyukuri Nikmat Allah (Jakarta: Raja Grafindo Persada, 2013). 111 ${ }^{25}$ Syafii el Bantanie, Dahsyatnya Syukur (Jakarta: Qultum Media, 2009). 2 
sangat besar untuk membantu kehidupan kita menjadi lebih tentang dalam menjalani kehidupan yang penuh dengan tantangan ini. ${ }^{26}$

\section{Perspektif Psikologi Positif tentang Terapi Syukur dalam Membentuk Pribadi Altruis}

Pemakanaan syukur tidak hanya bisa dilihat dari perspektif psikologi Islam yang terkandung dalam dimensi Qur'ani, namun juga bisa dianalisis dari perspektif psikologi positif yang memiliki konsep tersendiri mengenai bagaimana konsep syukur itu dimaknai secara detail. Konsep syukur dalam psikologi positif memang berbeda dengan konsep syukur dalam psikologi Islam yang berlandaskan al-Qur'an. Syukur dalam psikologi positif lebih menitikberatkan pada perasaan atau emosi positif yang mendorong seseorang untuk berbagi kepada sesama sebagai bentuk penghargaan dan apresiasi atas kerja keras yang sudah dilakukan. Syukur dalam psikologi positif tidak mengambil intisari yang terdapat dalam al-Qur'an, karena apa yang hendak dicapai adalah munculnya perasaan dan niat baik untuk menghargai orang yang telah berbuat kepada diri sendiri.

Kajian syukur dalam psikologi positif pertama kali dilakukan oleh Robert A. Emmons dan Michael E. McCullough, yang berupaya mencari kekuatan atau energi positif dalam jiwa orang yang bersyukur. Sebelumnya, konsep syukur belum terjamah dalam kajian keilmuan psikologi, sehingga mendorong Robert Emmons melakukan penelitian pada tahun 1998. Penelitian pertama Robert Emmons melibatkan para mahasiswa untuk menuliskan lima hal yang menjadikan mereka bisa bersyukur setiap hari. Sementara mahasiswa selebihnya diminta untuk mencatat lima hal yang membuat mereka berkeluh kesah atau tidak puas dengan apa yang sudah dijalaninya. Tiga pekan kemudian, mahasiswa yang bersyukur memberitakan bahwa ada peningkatan dalam masalah kesehatan dan semakin membaiknya hubungan sosial diantara teman-teman mereka.

Terlepas dari munculnya penelitian pertama kali konsep syukur, kita perlu memahami terminologi syukur dalam psikologi positif. Ini karena, syukur dalam psikologi positif berbeda sudut pandang dengan syukur dalam psikologi qur'ani, sehingga kita bisa mengintegrasikan keduanya dalam berbagai aspek kehidupan. Syukur atau rasa kebersyukuran dalam ilmu psikologi sering disebut dengan istilah gratitude. Kata gratitude

\footnotetext{
${ }^{26}$ David G Myer, Psikologi Sosial.IV
} 
sendiri berasal dari bahasa latin, "gratia", yang berarti kelembutan, kebaikan, dan kemurahan hati serta "gratus", yang berarti menyenangkan. Makna dari bahasa latin berarti seseorang harus melakukan suatu kebaikan, kemurahan hati, dan kesenangan memberi dan menerima tanpa ada tujuan apa pun, kecuali hanya berbuat baik kepada sesama. ${ }^{27}$

Gratitude dalam psikologi positif diartikan sebagai sebuah rekognisi positif ketika menerima sesuatu yang menguntungkan dan menyenangkan, atau nilai tambah yang berkaitan dengan penilaian bahwa ada pihak lain yang bertanggung jawab akan keberadaan nilai tambah tersebut. ${ }^{28}$ Pengakuan terhadap pemberian orang lain termasuk bagian penting dari rasa syukur yang diucapkan oleh seseorang. Dalam psikologi positif, syukur termasuk salah satu kunci esensial bagi seseorang untuk memperoleh kepuasan diri atas apa yang sudah dicapai, melalui penghargaan atau rasa terimakasih kepada orang lain.

Syukur dalam psikologi positif adalah sikap yang menimbulkan kesadaran untuk memberi sesuatu yang bermanfaat bagi orang lain tanpa butuh dipuji atau dihargai. ${ }^{29}$ Sebagai sebuah komponen psikologis, syukur memang melibatkan emosi dan perasaan dalam diri untuk bersikap rendah hati atas apa yang sudah dicapai tanpa bersikap sombong atau merasa paling hebat di lingkungan sekitar. Konsep syukur dalam dimensi psikologi positif sebenarnya adalah membuka dan menampakkan limpahan nikmat bukan untuk sekadar kepentingan sendiri, namun juga ada perasaan positif untuk berbagi kebahagiaan dengan orang lain.

Syukur merupakan emosi positif yang mendorong orang untuk berbagi kebaikan, karena kekayaan atau limpahan nikmat yang dimiliki hanyalah bersifat sementara. Ketika seseorang terbiasa mengucapkan terimakasih atas pemberian orang lain atau tidak pernah lupa untuk bersyukur, maka ia akan menjadi pribadi yang disayangi dan dicintai oleh semua orang. Pribadi yang bersyukur adalah mencerminkan hidup dengan penuh kemurahan dan kemurnian hati dalam memberikan sesuatu kepada orang atau beramal saleh kepada sesama manusia. Dalam kehidupan sehari-hari, syukur sebenarnya sudah

\footnotetext{
${ }_{27}$ Robert A Emmons, "The Psychology of Gratitude: An Introduction". Dalam R.A. Emmons, \& M.E. McCullough, The Psychology of Gratitude (New York: Oxford University Press, 2004).44

${ }^{28}$ Ibid. 45

${ }^{29}$ Roberts Emmons and Richard McCullough, "Counting Blessings Versus Burdens: An Experimental Investigation of Gratitude and Subjective Well-Being in Daily Life," Journal of Personal Social Psychology 2 (84) (2003): 377-389.
} 
tertanam dalam pribadi setiap orang, namun terkadang terjebak dengan nafsu dan ambisi yang berlebihan. ${ }^{30}$

Gratitude atau syukur dalam psikologi positif merupakan semacam rasa takjub, penuh rasa terimakasih, penghargaan terhadap nikmat kehidupan. Perasaan yang berdampak positif tersebut bisa ditunjukkan kepada sesama manusia atau bahkan kepada Tuhan yang memberi beragam kenikmatan di dunia ini. Dari situ, sikap syukur mendorong setiap individu untuk melakukan suatu perbuatan baik (virtue), yang nanti berhubungan atau berkolerasi positif dengan peningkatan sikap altruistik terhadap orang lain. Ini karena, berbagi kebaikan atau kenikmatan adalah wujud nyata dari rasa syukur yang menjadi langkah penting bagi seseorang untuk menjadi pribadi yang berguna bagi siapa pun di dunia ini. ${ }^{31}$

Berbagai penelitian ilmiah modern sudah dilakukan untuk menunjukkan betapa kekuatan syukur menjadi salah satu kajian dari psikologi positif yang dampaknya langsung dirasakan oleh pelakunya sendiri. Dalam wilayah psikologi positif, istilah syukur dikenal dengan gratitude sebagai sebuah keutamaan dalam meningkatkan dan melindungi kebahagiaan maupun well-being.Dari sini psikologi positif adalah studi tentang emosi positif untuk meningkatkan kualitas hidup manusia, terutama berkaitan dengan perilaku syukur yang menjadi bagian penting dalam kajian psikologi modern dewasa ini.

Energi syukur dalam konteks psikologi positif belakangan ini menjadi kajian penting yang sebelumnya sama sekali tidak pernah tersentuh oleh psikolog kenamaan di berbagai belahan dunia. Psikologi positif sendiri didirikan oleh Martin E.P. Seligman yang saat itu baru terpilih sebagai presiden American Psychological Association. Dengan berdirinya psikologi positif yang berfokus pada kualitas hidup manusia agar menjadi lebih baik, maka dimensi syukur menjadi salah satu kajian penting yang terus dikembangkan sampai sekarang. ${ }^{32}$

Kekuatan syukur ternyata tidak hanya berpengaruh pada aspek keberimanan seseorang, tetapi juga meluas kepada aspek sosial yang lebih luas, yakni dapat menuntun

\footnotetext{
${ }^{30}$ Robert A Emmons, Thanks! How The New Science of Gratitute Can Make You Happier (New York: Houghton Mifflin Company, 2007).4

${ }^{31}$ Robert A Emmons and C.M. Shelton, Gratitude and the Science of Positive Psychology" In C.R.Snyder, Lopez, J. Shane, Handbook of Positive Psychology (New York: Oxford University Press, 2002).134

${ }^{32}$ David Carr, Perspective on Gratitude: An Interdisciplinary Approach. New York: Routledge.23
} 
manusia untuk menjadi pribadi yang altruis. Hal ini menjadi penting untuk melihat korelasi antara rasa syukur dengan perilaku altruisme yang melekat dalam diri seseorang yang sudah ditempa dengan nilai-nilai keimanan yang sangat kuat.

Perspektif psikologi positif memberikan pandangan positif tentang pentingnya hidup dalam emosi dan hasrat yang tidak berlebihan dalam menyikapi setiap limpahan rahmat dari Tuhan. Dari pemikiran psikologi positif ini, setiap manusia bisa merefleksikan bahwa faktor penting yang mendorong terbentuknya pribadi yang altruis adalah energi syukur yang selalu bersemayam dalam relung-relung hati setiap manusia.

Pemaknaan wawasan syukur dalam perspektif ini, diharapkan membuka kesadaran manusia untuk tidak antipati dengan kenikmatan yang diperoleh setiap harinya. Ini karena, wawasan syukur berkaitan langsung dengan ekspresi diri tentang pujian dan perasaan terimakasih kepada Tuhan yang telah memberikan beragam karunia dan anugerah yang tidak terhingga sehingga manusia di dunia tidak mungkin bisa menghitung nikmat kebaikan yang dipancarkan ke muka bumi.

Kekuatan daya syukur dalam diri manusia adalah ketika seseorang mampu menyadari bahwa kenikmatan yang diperoleh bukan hanya untuk kepentingan sendiri atau kelompok, melainkan juga untuk kepentingan semua umat yang membutuhkan pertolongan. Sudah saatnya perilaku syukur menjadi terapi untuk menggerakan kesalehan sosial dalam diri manusia, karena di saat seseorang mengalami penderitaan sekalipun, orang yang bersyukur akan senantiasa bersikap menerima apa yang menjadi ketentuan dari sang ilahi.

Dalam kondisi zaman yang menonjolkan sikap egoisme dan keserakahan ini, perilaku syukur tampaknya merupakan solusi efektif untuk mengatasi masalah krisis kemanusiaan modern yang selalu mementingkan kepentingan sendiri dibandingkan dengan kepentingan orang lain. Dalam penelitian ilmiah modern sudah dilakukan analisa yang mendalam terhadap perilaku syukur yang mampu meningkatkan sikap empatik seseorang ketika berinteraksi dengan lingkungan sosial dan berbaur dengan masyarakat secara keseluruhan. ${ }^{33}$

Perilaku syukur dalam konteks kehidupan praktis ternyata mampu memberikan dorongan bagi seseorang untuk berbagi kepada sesama yang membutuhkan pertolongan.

\footnotetext{
${ }^{33}$ Roberts Emmons and Richard McCullough, "Counting Blessings Versus Burdens: An Experimental Investigation of Gratitude and Subjective Well-Being in Daily Life." 464
} 
Tidak heran bila penelitian psikologi positif tentang syukur telah membuka cakrawala pemikiran manusia bahwa kekayaan tidak akan bermakna apabila hanya dinikmati oleh kepentingan sendiri. Perilaku syukur di sini adalah sebuah gerakan yang bisa membangkitkan naluri dalam hati untuk tidak melupakan orang lain yang berada di sekitar kita. Kemampuan mendayagunakan energi syukur merupakan bagian dari spirit keimanan untuk menjalankan fungsi kekhalifahan di muka bumi, yakni memberikan manfaat bagi orang lain. Sebagai mahluk yang berakal, manusia diberikan insting untuk saling berbagi dengan sesama tanpa menonjolkan diri sebagai orang yang sombong. Ini karena, manusia ditakdirkan Tuhan untuk hidup berkelompok atau bersosial dengan senantiasa memberikan pertolongan kepada orang yang membutuhkan.

Bagi orang-orang yang beriman, perilaku syukur seolah sudah menjadi hiasan hidup yang mengawal segala tindakan dalam melakukan suatu pekerjaan tertentu. Kekuatan syukur yang memberikan spirit bagi orang-orang beriman terletak pada kesadaran diri tentang pentingnya berbagi kenikmatan kepada orang lain. Orang yang menjadi kebersyukurannya, selalu memikirkan kepentingan orang lain, terutama untuk kepentingan umat dalam menjalankan ibadah maupun sarana pendidikan. Dalam konteks praktis, orang yang bersyukur selalu terpanggil dan tergerak untuk mengatasi masalah kemiskinan, kemelaratan, dan penyakit sosial yang terjadi dalam kehidupan masyarakat.

\section{Kesimpulan}

Dalam psikologi qur'ani, perilaku syukur merupakan salah satu maqam tasawuf yang sangat besar pengaruhnya terhadap terbentuknya pribadi muslim yang berjiwa sosial atau altruistik. Ini karena, perilaku syukur dalam psikologi qur'ani mendorong setiap orang untuk berbagi kenikmatan dan kebahagiaan kepada orang yang sedang tertimpa kesusahan. Meskipun dalam situasi krisis sekalipun, orang-orang yang bersyukur memiliki kemampuan menerima semua ketentuan Allah dengan penuh keikhlasan tanpa ada prasangka yang berlebihan. Bahkan, di saat situasi seperti itu, orang yang berada pada zona syukur, akan selalu terdorong untuk berbagi kenikmatan dan karunia kepada orang yang lebih membutuhkan. Ketika itulah, syukur menjadi terapi sufistik untuk menyembuhkan virus-virus egosentrisme yang mewarnai dinamika kehidupan manusia modern. 
Sementara, dalam perspektif psikologi positif, orang-orang yang memiliki tradisi kuat dalam bersyukur kepada Tuhan, memiliki kemampuan menyelami jiwa dan batin orang lain dengan penuh empatik. Meskipun tidak memiliki banyak harta, orang yang bersyukur cenderung lebih dermawan dan rendah hati dibandingkan dengan orang-orang kaya. Kaum yang bersyukur lebih cenderung untuk mengakui keyakinan akan keterkaitan seluruh kehidupan, serta rasa ikatan dan tanggung jawab terhadap orang lain. Pribadi-pribadi yang bersyukur dilaporkan memiliki sifat materialistis yang rendah. Mereka tidak begitu menaruh perhatian penting pada hal-hal yang bersifat materi. Mereka cenderung tidak menilai keberhasilan atau keberuntungan diri mereka sendiri dan orang lain dari jumlah harta benda yang mereka kumpulkan.

\section{Kepustakaan}

Ahmad Taufik Nasution. Melejitkan SQ Dengan Prinsip 99 Asmaul Husna: Merengkuh Puncak Kebahagiaan Dan Kesuksesan Hidup. Jakarta: PT. Gramedia Pustaka Utama, 2009.

Aliah B Hasan, and Purwakania. Psikologi Perkembangan Islami (Menyingkap Rentang Kehidupan Manusia Dari Prakelahiran Hingga Pasca Kematian). Jakarta: RajaGrafindo Persada, 2006.

Amir An-Najar. Psikoterapi Sufistik Dalam Kehidupan Modern. Bandung: PT. Mizan Publika, 2004.

Aura Husna. Kaya Dengan Bersyukur: Menemukan Makna Sejati Bahagia Dan Sejahtera Dengan Mensyukuri Nikmat Allah. Jakarta: RajaGrafindo Persada, 2013.

al-Baqi, Abd, and Muhammad Fuad. “Al-Mu'jam Al-Mufahras Li Al-Fadl Al-Qur'an.” Mesir: Dar al-Fikri (1981).

Charles T Tart. Altered States of Consciousness. New York: Doubleday \& Company., 1972.

David Carr. Perspective on Gratitude: An Interdisciplinary Approach. New York: Routledge. New York: Routledge, 2016.

David G Myer. Psikologi Sosial. Jakarta: Salemba Humanika, 2012.

Desmita. Psikologi Perkembangan. Bandung: Remaja Rosdakarya, 2008.

Fuad Nashori. Psikologi Sosial Islami. Jakarta: PT. Refika Aditama, 2008.

J. Spencer Trimingham. The Sufi Orders in Islam. London \& Oxford: Oxford University Press, 1973. 
M Qurais Shihab. Wawasan Al-Qur'an: Tafsir Maudhu'i Atas Pelbagai Persoalan Umat. Bandung: Mizan, 1996.

M.I El-Firdausy. Rahasia Kedahsyatan Syukur. Semarang: One Book, 2008.

Muhammad Khalid Tsabit. Quantum Ridha: I'tibar Kesejukan Hati, Kemuliaan Pribadi Terhadap Qadha Ilahi. Jakarta: Amzah, 2009.

Robert A Emmons. Thanks! How The New Science of Gratitute Can Make You Happier. New York: Houghton Mifflin Company, 2007.

- - . "The Psychology of Gratitude: An Introduction". Dalam R.A. Emmons, \& M.E. McCullough, The Psychology of Gratitude. New York: Oxford University Press, 2004.

Robert A Emmons, and C.M. Shelton. Gratitude and the Science of Positive Psychology" In C.R.Snyder, Lopez, J. Shane, Handbook of Positive Psychology. New York: Oxford University Press, 2002.

Roberts Emmons, and Richard McCullough. "Counting Blessings Versus Burdens: An Experimental Investigation of Gratitude and Subjective Well-Being in Daily Life." Journal of Personal Social Psychology 2 (84) (2003): 377-389.

Sachiko Murata, and William Chittick. The Vision of Islam. Yogyakarta: Suluh Press, 2005.

Satriyo. Meditasi Syukur 20 Menit. Yogyakarta: Kanisius, 2009.

Syafii el Bantanie. Dahsyatnya Syukur. Jakarta: QultumMedia, 2009.

Syekh Fadhalla. Al-Hikam: 264 Hikmah Dan Renungan Spiritual Harian Ibn Athaillah. Jakarta: Serambi, 2013.

Ulya Uli Ubaid. Sabar Dan Syukur Gerbang Kebahagiaan Dunia Dan Akhirat. Jakarta: Bumi Aksara, 2014. 